Equilibrium : Jurnal Pendidikan Vol. X. Issu 1. Januari-April 2022

\title{
Implementasi Pembelajaran Tatap Muka Terbatas dan Daring Masa Kenormalan Baru Pada Anak Usia Dini di Kabupaten Kediri
}

\author{
Veny Iswantiningtyas ${ }^{1}$ Dema Yulianto ${ }^{2}$ Hanggara Budi Utomo ${ }^{3}$ \\ ${ }^{1}$ Program Studi PG-PAUD, FKIP Universitas Nusantara PGRI Kediri \\ Email: veny@unpkediri.ac.id \\ ${ }^{2}$ Program Studi PG-PAUD, FKIP Universitas Nusantara PGRI Kediri \\ Email: dema@unpkediri.ac.id \\ ${ }^{3}$ Program Studi PG-PAUD, FKIP Universitas Nusantara PGRI Kediri \\ Email: hanggara@unpkediri.ac.id
}

\begin{abstract}
This study aims to determine how the implementation of limited face-to-face and online learning in early childhood in the new normal period in Kediri Regency. A descriptive-analytical approach was used in this study. The technique of determining the informants used the snowball sampling technique. Collecting and extracting data using observation and interviews with teachers and principals of Kindergarten Dharma Wanita Klanderan II Kediri Regency, as well as reviewing school academic documents. The data analysis technique uses an interactive analysis model. The findings in this study are the application of new normal face-to-face learning during the COVID-19 pandemic at Kindergarten Dharma Wanita Klanderan II, Kediri Regency in accordance with the health protocols that have been set by the government, both central and local governments. On the other hand, to support face-to-face learning directly, Dharma Wanita Klanderan II Kindergarten in Kediri Regency applies online learning or learning from home with the involvement of parents of students who are very cooperative.
\end{abstract}

Keywords : Limited Face-To-Face Learning; Early Childhood; New Normal; Online

Abstrak. Penelitian ini bertujuan untuk mengetahui bagaimana pelaksanaan pembelajaran tatap muka terbatas dan daring pada anak usia dini di masa new normal di Kabupaten Kediri. Pendekatan deskriptif analitis digunakan dalam penelitian ini. Teknik penentuan informan menggunakan teknik snowball sampling. Pengumpulan dan penggalian data menggunakan metode observasi dan wawancara pada guru dan kepala sekolah Taman Kanak-kanak Dharma Wanita Klanderan II Kabupaten Kediri, serta mengkaji dokumen akademik sekolah. Teknik analisis data menggunakan model analisis interaktif. Temuan dalam penelitian ini adalah penerapan pembelajaran tatap muka new normal masa pandemi covid-19 di Taman Kanak-kanak Dharma Wanita Klanderan II Kabupaten Kediri sesuai dengan protokol kesehatan yang telah di tetapkan oleh pemerintah, baik pemerintah pusat maupun pemerintah daerah. Sisi yang lain, untuk menunjang pembelajaran tatap muka secara langsung tersebut, Taman Kanak-kanak Dharma Wanita Klanderan II Kabupaten Kediri menerapkan pembelajaran daring atau belajar dari rumah dengan pelibatan orang tua anak didik yang sangat kooperatif.

Kata Kunci : Pembelajaran Tatap Muka Terbatas; Anak Usia Dini; New Normal; Daring

\section{PENDAHULUAN}

Pandemi COVID-19 telah mengakibatkan gangguan terbesar pada sistem pendidikan dalam sejarah, yaitu dengan penutupan sekolah yang berdampak pada sekitar $94 \%$ populasi siswa dunia (United Nations, 2020). Pandemi covid-19 yang terus melanda membuat proses pembelajaran yang semula dilakukan tatap muka harus beralih menjadi pembelajaran secara daring, dan menjadikan berbagai pihak harus menyesuaikan diri agar proses pembelajaran tetap berjalan. Hal ini senada 
dengan pernyataan dari UNESCO bahwa pandemi covid-19 berdampak pada bidang pendidikan (Prima, 2020), dan hampir 300 juta siswa merasa terancam akan hak pendidikannya karena wabah ini (Handoyo, 2020). Pemerintah Indonesia melalui Menteri Pendidikan dan Kebudayaan Republik Indonesia mengeluarkan kebijakan terkait pencegahan penularan Covid-19 di satuan pendidikan dan kebijakan terkait proses belajar selama pandemi melalui surat edaran nomor 03 tahun 2020 dan Surat Edaran nomor 4 tahun 2020 (Kemdikbud, 2020a., 2020b). Inti dari kebijakan tersebut adalah mengharuskan seluruh siswa untuk belajar dari rumah atau melakukan pembelajaran jarak jauh (PJJ). Kebijakan ini diterapkan untuk lembaga sekolah formal maupun informal, mulai dari tingkatan dasar, menengah, sampai perguruan tinggi. Adanya kondisi pembelajaran jarak jauh ini, di satu sisi memberikan dampak positif karena seluruh peserta didik terlindungi dari paparan virus corona ini. Namun demikian, hal ini memungkinkan ada dampak lain juga yang akan mempengaruhi aktifitas dan proses pembelajaran peserta didik, khususnya untuk peserta didik pada jenjang pendidikan anak usia dini.

Istilah pembelajaran daring dan luring di perkenalkan di era teknologi informasi pada saat ini. Pembelajaran daring adalah metode belajar yang menggunakan model interaktif berbasis Internet dan Learning Management System (LMS), dan menggunakan aplikasi video conference seperti zoom, google meet, aplikasi penyimpanan seperti google drive, dan aplikasi lain yang relevan. Kegiatan daring diantaranya webinar, kelas online, seluruh kegiatan dilakukan menggunakan jaringan internet dan komputer (Simanihuruk dkk., 2019). Selain itu, Sadikin dan Hamidah (2020) menyatakan pembelajaran daring merupakan pembelajaran yang memanfaatkan internet (network) dengan aksebilitas, konektivitas, fleksibilitas, dan keahlian dalam mengadakan jenis interaksi dalam pembelajaran.

Dinamika pembelajaran tatap muka ke dalam bentuk digital dapat memunculkan permasalahan tersendiri bagi orang tua, guru, dan lain-lain. Menurut Fahlena (2021)menyatakan kendala orang tua dalam mendampingi anak belajar di rumah adalah kurangnya pemahaman materi oleh orang tua, kesulitan orang tua dalam menumbuhkan minat belajar anak, tidak memiliki cukup waktu untuk mendampingi anak karena harus bekerja, orang tua tidak sabar dalam mendampingi anak saat belajar di rumah, kesulitan orang tua dalam mengoperasikan media, dan kendala terkait jangkauan layanan internet. Sisi yang lain, kendala lain yang dihadapi oleh orangtua dalam mendidik anak usia dini pada saat pandemi covid-19 di pengaruhi faktor eksternal dan internal, yaitu mengalami kelelahan psikologis dalam hal mendidik anak dan kurang memahami media pembelajaran (Mufaziah \& Fauziah, 2020; Zahra dkk., 2021)

Masa pandemi covid-19 juga berdampak pada kualitas guru PAUD. Guru PAUD mengalami kendala mengajar pada empat indikator yaitu kendala komunikasi, metode pembelajaran, materi sarana, prasarana, dan biaya serta penggunaan teknologi (Agustin, dkk. 2021; Harahap, dkk. 2021). Ketika guru PAUD mengalami kendala dalam pelaksanaan pembelajaran daring, maka hal ini berimbas pada perkembangan anak usia dini. Sebagian besar aspek perkembangan pada anak Taman Kanak-kanak mengalami penurunan. Sebagian besar aspek perkembangan anak usia dini mengalami penurunan pada perkembangan nilai agama dan moral, perkembangan fisik-motorik, perkembangan bahasa, dan perkembangan sosio-emosi. Tingkat penurunan yang cukup besar yaitu dalam aspek fisik-motorik dan sosial emosional anak (Pratiwi \& Zulminiati, 2021; Wulandari \& Purwanta, 2020)

Kondisi pembelajaran daring saat ini memang belum bisa dikatakan ideal sebab masih terdapat berbagai hambatan yang dihadapi. Namun demikian, pembelajaran daring tetap dapat memfasilitasi kebutuhan belajar anak didik untuk mengembangkan kemampuan bakat dan minat anak, sehingga pembelajaran daring masih efektif untuk dilanjutkan agar kegiatan akademik anak dapat berjalan di tengah pandemic covid-19 ini (Shaleh \& Anhusadar, 2021). Oleh karena itu, perlu adanya kombinasi dua model pendekatan dalam pembelajaran yaitu pembelajaran daring dan luring yang meliputi belajar tatap muka terbatas, belajar dari rumah, dan kunjungan kerumah. Pembelajaran luar jaringan (luring) adalah suatu sistem pembelajaran yang didalamnya ada beberapa metode seperti kunjungan rumah (home visit) dan shift (bergantian) dengan menggunakan media, materi, lembar kerja anak, media, modul belajar mandiri, dan bahan ajar cetak yang berada 
disekitar lokasi lingkungan rumah yang telah dipersiapkan oleh pendidik (Suhendro, 2020).

Berdasarkan data Dirjen Pendidikan Anak Usia Dini, Pendidikan Dasar, dan Pendidikan Menengah (PAUD Dikdasmen) Kemdikbudristek bahwa jumlah sekolah yang melaksanakan pembelajaran luring atau tatap muka terbatas terus meningkat. Sebanyak 85 persen dari 435.650 sekolah mulai dari tingkat SD sampai SMA di Indonesia hingga September 2021 siap melaksanakan pembelajaran tatap muka terbatas. Sekitar $7,17 \%$ sekolah sudah menjalankan pembelajaran tatap muka terbatas secara nasional, sedangkan sisanya $72,83 \%$ masih melaksanakan pembelajaran daring (Bona, 2021).

Pemerintah mulai menginstruksikan dimulainya Pembelajaran Tatap Muka (PTM) terbatas kala penularan Covid-19 mulai terkendali. Dasar kebijakan dilakukannya pembelajaran tatap muka terbatas karena pemerintah mulai mengkhawatirkan peserta didik mengalami ketertinggalan pendidikan (learning loss) selama menjalani pembelajaran daring. Hal tersebut akan berimbas pada kualitas sumber daya manusia Indonesia beberapa tahun ke depan. Menteri Pendidikan, Kebudayaan, Riset, dan Teknologi (Mendikbud Ristek) Nadiem Makarim menyatakan saat ini ada 80 hingga 85 persen masyarakat yang mendukung kebijakan PTM di sekolah. Berdasarkan data dari Kompasiana (2021) bahwa pada tanggal 22 Oktober 2021 Pemerintah daerah mengeluarkan kebijakan daerah mengenai diizinkannya kegiatan pembelajaran secara tatap muka tetapi secara terbatas, atau disebut dengan istilah PTMT (Pembelajaran Tatap Muka Terbatas).

Dimasa pandemi covid-19 berbagai cara telah dilakukan oleh berbagai pihak sekolah untuk pembelajaran tetap berlangsung seperti menerapkan pembelajaran daring dan pembelajaran luring. Walaupun terkadang tujuan pembelajaran yang ingin di sampaikan belum tercapai dengan baik, akan tetapi di harapkan dari proses tersebut di harapkan perserta didik mampu menerima pembelajaran baik pembelajaran daring ataupun pembelajaran luring, termasuk upaya yang di lakukan sekolah untuk mencerdaskan peserta didiknya (Listiningrum dkk., 2020; Pratama \& Mulyati, 2020; Zulaiha dkk., 2020)

Berdasarkan pemaparan di atas, kami selanjutnya melakukan observasi tentang pelaksanaan pembelajaran di Taman Kanak-Kanak Dharma Wanita Klanderan II Desa Klanderan Kecamatan Plosoklaten Kabupaten Kediri dimana pembelajaran menggunakan pembelajaran daring dan luring. Pembelajaran luring menggunakan pembelajaran tatap muka terbatas, sedangkan daring menggunakan whatsapp group (WAG). Pelaksanaan pembelajaran tatap muka terbatas di sekolah tersebut bahwa setiap anak memiliki jadwal masuk secara bergantian sehingga anak-anak merasa senang dapat kembali belajar dan bermain di sekolah, meskipun masih terbatas. Satgas Penanganan Covid-19 Kabupaten Kediri memberikan rekomendasi kepada satuan pendidikan setingkat PAUD untuk pelaksanaan Pembelajaran Tatap Muka (PTM). Satuan pendidikan tetap melayani proses pembelajaran bagi peserta didik yang belum diizinkan oleh orang tua untuk mengikuti PTM terbatas dengan metode belajar dari rumah atau daring, atau metode lainnya. Satgas Penanganan Covid-19 di sekolah untuk bertanggung jawab dalam pendisiplinan pelaksanaan protokol kesehatan.

Penelitian ini bertujuan untuk mengetahui bagaimana pelaksanaan pembelajaran tatap muka terbatas dan daring pada anak usia dini di masa new normal di Taman Kanak-Kanak Dharma Wanita Klanderan II Desa Klanderan Kecamatan Plosoklaten Kabupaten Kediri.

\section{METODE PENELITIAN}

Jenis penelitian yang digunakan dalam penelitian ini adalah penelitian kualitatif yang bertujuan mengeksplorasi dan memahami makna yang berasal dari masalah-masalah sosial (Creswell, 2015). Pendekatan deskriptif analitis digunakan dalam penelitian ini untuk mengungkap kejadian yang berhubungan dengan kondisi sekarang, yaitu tentang kondisi pelaksanaan pembelajaran tatap muka pada masa new normal di Taman Kanak-kanak Dharma Wanita Klanderan II Desa Klanderan Kecamatan Plosoklaten Kabupaten Kediri secara alamiah, bukan dalam kondisi terkendali. Teknik penentuan informan menggunakan teknik snowball sampling. Pengumpulan dan penggalian data menggunakan metode observasi dan wawancara pada guru dan kepala sekolah Taman Kanak-kanak Dharma Wanita Klanderan II Desa Klanderan Kecamatan Plosoklaten Kabupaten 
Kediri, serta mengkaji dokumen akademik sekolah, seperti halnya standar operasional prosedur, RPPH, RPPM, catatan harian yang didokumentasikan oleh guru kelas. Teknik analisis data menggunakan model analisis interaktif yang terdiri atas pengumpulan data, reduksi data, penyajian data, dan kesimpulan (Sugiyono, 2017).

\section{HASIL PENELITIAN DAN PEMBAHASAN}

\section{Hasil Penelitian}

Selama masa pandemi covid-19, Pemerintah Republik Indonesia selalu mengedepankan dan menekankan pada prioritas kesehatan dan keselamatan dalam penyelenggaraan pendidikan di Indonesia. Penekanan lebih mengarah pada tumbuh kembang anak didik serta hak anak didik selama pandemi covid-19. Seiring berjalannya waktu dan kondisi pandemi covid-19 yang semakin kondusif, maka Pemerintah Republik Indonesa melalui Surat Keputusan Bersama (SKB) empat Menteri mengeluarkan kebijakan pembelajaran tatap muka terbatas secara bertahap agar semakin dapat meningkatkan kualitas belajar lebih terukur (Menteri Pendidikan Dan Kebudayaan dkk., 2021). Hal ini mengindikasikan bahwa memasuki tahun akademik 2021/2022 penyelenggaran pembelajaran tatap muka dilaksanakan di Indonesia dengan berlandaskan ketentuan SKB 4 Menteri. Selama pandemi covid-19, tidak sedikit anak didik dan guru merindukan agar segera dilaksanakan pembelajaran tatap muka secara langsung, apalagi selama pembelajaran daring sangat dipengaruhi oleh kualitas media daring dan tentunya jaringan internet sebagai hal yang penting dalam pelaksanaan pembelajaran daring. Oleh karena itu, melalui SKB 4 Menteri tentang panduan penyelenggaraan pembelajaran di masa pandemi covid-19 dapat membawa harapan baru peningkatan kualitas belajar anak didik ketika merindukan pembelajaran tatap muka terbatas.

Pelaksanaan pembelajaran tatap muka pada jenjang Pendidikan Anak Usia Dini di Kabupaten Kediri sudah mendapatkan ijin dari Bupati, sesuai arahan dari Kepala Dinas Pendidikan Kabupaten Kediri Bidang Kependidikan. Kami menemukan hasil bahwa pelaksanaan pembelajaran tatap muka masa new normal yang dilaksanakan oleh TK Dharma Wanita Klanderan II Desa Klanderan Kecamatan Plosoklaten Kabupaten Kediri ini dimulai pada Selasa, 14 September 2021 dengan mengikuti standar operasional prosedur (SOP) yang telah disusun sebagai dasar pengumpulan data. Beberapa administrasi telah dipenuhi oleh TK Dharma Wanita Klanderan II Desa Klanderan Kecamatan Plosoklaten Kabupaten Kediri untuk melaksanakan pembelajaran tatap muka masa new normal ini di antaranya surat pernyataan atau surat ijin dari orang tua, komite sekolah, dan Kepala Desa setempat, serta membuat surat pemberitahuan pelaksanaan pembelajaran tatap muka terbatas masa new normal yang ditujukan kepada camat, Danramil, Kapolsek, dan puskesmas dengan mengetahui Koordinator Wilayah Bidang kependidikan. Persyaratan lainnya yaitu pihak TK Dharma Wanita Klanderan II Desa Klanderan Kecamatan Plosoklaten Kabupaten Kediri adalah membuat video simulasi pelaksanaan pembelajaran yang berdurasi lima sampai dengan sepuluh menit untuk memberikan gambaran bagi peserta didik, orang tua serta masyarakat sekitarnya.

Pelaksanaan standar operasional prosedur pembelajaran tatap muka masa new normal TK Dharma Wanita Klanderan II Desa Klanderan Kecamatan Plosoklaten Kabupaten Kediri adalah sebagai berikut: 1) apabila terdapat guru, tenaga kependidikan, dan anak didik dengan kondisi kurang sehat disarankan untuk istirahat dirumah; 2) waktu pembelajaran tatap muka dibatasi selama 1 jam dimana dimulai pukul 07.30 wib dan diakhiri pukul 08.30 wib tanpa istirahat dan makan bersama; 3) pelaksanaan pembelajaran tatap muka terbatas adalah dua kali setiap minggu, dan untuk hari lain dilaksanakan secara daring; 4) bagi orang tua yang mengantar diharap langsung pulang dan tidak boleh menunggu di sekolah; 5) sekolah melaksanakan protokol kesehatan yang mencakup 5M (mencuci tangan, memakai masker, menjaga jarak, menjauhi kerumunan, dan mengurangi mobilitas; 6) saat anak datang ke sekolah diperiksa suhu badannya dan di catat oleh guru dengan menggunakan thermogun. Anak diarahkan mencuci tangan memakai sabun dan air mengalir serta disediakan tisu. Sebelum masuk ruangan kelas, anak diberi semprotan handsanitizer; 7) meniadakan pedagang makanan di sekitar sekolah; 8) sehari sekali ruang kelas dan lokasi sekolah disemprot dengan disinfektan; 9) anak didik membawa peralatan tulis sendiri tidak boleh bergantian; 
10) sepatu dan tas diletakkan di luar ruangan kelas; 11) guru dan anak harus memakai masker yang menutupi hidung dan mulut sampai dagu selama berada di lingkungan sekolah; 12) menerapkan etika batuk atau bersin; dan 12) ketika anak akan pulang sekolah, guru akan memeriksa suhu tubuh anak dan mencatatnya.

Persyaratan pelaksanaan pembelajaran tatap muka terbatas tersebut didukung dengan kajian yang dilakukan oleh Shaleh dan Anhusadar (2021) tentang kesiapan pembelajaran pada lembaga Paud di Kendari, dimana perilaku hidup bersih dan sehat adalah hal wajib dilakukan di lingkungan sekolah agar dapat meminimalisir dan mencegah penularan virus. Perilaku hidup bersih dan sehat harus sudah dibiasakan sejak anak usia dini. Hal ini senada dengan kajian penelitian yang dilakukan oleh Safitri dan Harun (2020) bahwa pembiasaan pola hidup bersih dan sehat dapat dibiasakan pada anak usia dini dengan beraneka ragam kegiatan yang positif, misalnya saja menyediakan makanan yang bergizi, membiasakan anak untuk berolahraga sederhana dan istirahat yang cukup, serta melakukan kegiatan berjemur setiap pagi antara 10-15 menit.

Selanjutnya, dalam pelaksanaan kegiatan pembelajaran tatap muka masa new normal, guru betul-betul memperhatikan jarak antar peserta didik seperti yang dianjurkan atau melakukan social/physical distancing di taman kanak-kanak (Shaleh \& Anhusadar, 2021). Pelaksanaan pembelajaran tatap muka langsung yang dilakukan guru di TK Dharma Wanita Klanderan II Desa Klanderan Kecamatan Plosoklaten Kabupaten Kediri meliputi kegiatan pendahuluan, inti, dan penutup. Adapun proses pembelajaran tatap muka yang dilaksanakan sebagai berikut: (a) kegiatan pendahuluan merupakan kegiatan awal pembelajaran yang bertujuan untuk memfokuskan perhatian dan membangkitkan motivasi sehingga anak didik siap untuk mengikuti kegiatan pembelajaran. TK Dharma Wanita Klanderan II Desa Klanderan Kecamatan Plosoklaten Kabupaten Kediri menerapkan kegiatan pendahuluan menggunakan model pembelajaran klasikal.

Kegiatan ini terlebih dahulu dilakukan guru dengan mengucapkan salam dan melakukan tanya jawab dengan anak (menanyakan kabar, menanyakan siapa teman yang tidak hadir, serta menanyakan hal yang anak semakin semangat dalam belajar), yang kenudian dilanjutkan dengan melakukan "Tepuk Semangat", berdo'a sebelum belajar, bernyanyi lagu "Aku Anak PAUD" sambil bertepuk tangan. Akhir kegiatan pendahuluan guru bercerita tentang tema yang akan dilakukan hari ini; (b) kegiatan inti merupakan suatu proses untuk mencapai kompetensi dasar yang dilakukan secara interaktif, inspiratif, menyenangkan, dan partisipatif. Kegiatan inti dilakukan melalui proses eksplorasi, eksperimen, elaborasi, dan konfirmasi. Kegiatan pembelajaran selama tatap muka sebelum pandemi di kegiatan inti adalah anak hanya mengerjakan 4 kegiatan, namun demikian pada masa pandemi ini anak hanya mengerjakan 1 kegiatan, itulah yang yang menjadi pembeda dalam aktivitas pembelajaran. Pelaksanaan kegiatan inti ini, terlebih dahulu guru memberikan arahan dan contoh cara mengerjakan tugas kemudian anak mengerjakan kegiatan.

Setelah anak selesai mengejakan tugas dari guru, anak-anak membereskan dan meletakkan kembali peralatan tulis di tempat yang telah disediakan. Tentunya bila ada anak yang belum selesai membereskan dan menata peralatan, maka guru menyuruh anak-anak menggunakan permainan yang telah disediakan di dalam kelas; (c) kegiatan penutup adalah kegiatan yang dilakukan untuk mengakhiri aktivitas pembelajaran. Bentuk kegiatannya berupa menyimpulkan, umpan balik, dan tindak lanjut. Kegiatan penutup merupakan bagian terakhir proses pembelajaran yang dimanifestasikan dengan menyimpulkan apa yang telah anak pelajari bersama-sama hari ini, kemudian guru menyampaikan pesan-pesan, membaca hadist pendek, berdo'a setelah belajar, menyanyikan lagu 'Pulang Sekolah TK' dan diakhiri mengucapkan salam.

Pembelajaran tatap muka secara langsung sebelum dan dimasa pandemi di Taman Kanakkanak Dharma Wanita Klanderan II Desa Klanderan Kecamatan Plosoklaten Kabupaten Kediri menggunakan model pembelajaran klasikal. Pangastuti (2001) mengemukakan bahwa model pembelajaran klasikal merupakan pola pembelajaran yang dilakukan guru bersama sekelompok peserta didik dalam satu kelas secara bersamaan dengan aktivitas dan waktu yang sama pula. Menurut Mulyasa (2012) model pembelajaran klasikal adalah pola pembelajaran yang dalam waktu sama, seluruh anak didik melakukan suatu kegiatan yang sama dalam satu kelas. Lebih lanjut, 
menurut Lisa (2018) menjelaskan bahwa penerapan pembelajaran klasikal dapat dirasakan manfaatnya secara langsung oleh anak. Materi pelajaran yang disampaikan perlu dikaitkan dengan pengetahuan dan pengalaman anak sehari-hari. Apabila materi pelajaran dirasa jauh dengan pengetahuan dan pengalaman anak, maka guru hendaknya memodifikasi materi pelajaran menjadi bentuk yang lebih sederhana, yakni membuat contoh sederhana sesuai dengan lingkungan anak. Selain itu, Syahrudin sebagaimana dikutip oleh Hijriati (2017) mengemukakan model pembelajaran klasikal masih sangat efektif untuk digunakan di PAUD, akan tetapi guru dituntut harus memberikan banyak pengalaman dan motivasi agar anak efektif ketika melakukan proses pembelajaran.

Kegiatan bermain dapat memberikan pengalaman dalam proses pembelajaran tatap muka terbatas untuk memberikan stimulasi perkembangan anak dalam melakukan kegiatan yang menyenangkan dan memotivasi anak untuk belajar (Widiastita \& Anhusadar, 2020). Namun demikian, guru perlu merancang pembuatan alat permainan edukatif berbasis kearifan lokal untuk mendukung kegiatan bermain selama tatap muka terbatas, karena menurut Utomo dkk. (2021) alat permainan edukatif berbasis kearifan lokal direkomendasikan di taman kanak-kanak sebagai media pembelajaran dalam mengenalkan kearifan lokal.

Kami juga menemukan hasil bahwa selain pelaksanaan pembelajaran tatap muka secara langsung di sekolah dimana pelaksanaan hanya dua kali selama sepekan, guru di Taman Kanak-kanak Dharma Wanita Klanderan II Desa Klanderan Kecamatan Plosoklaten Kabupaten Kediri juga menerapkan pembelajaran daring dengan harapan kebutuhan belajar anak dapat terpenuhi. Pelaksanaan pembelajaran daring lebih dikenal dengan istilah belajar dari rumah dilakukan oleh anak dengan adanya kerjasama antara guru dan orang tua anak didik. Berdasarkan hasil wawancara, belajar dari rumah yang dilakukan anak TK Dharma Wanita Klanderan II Desa Klanderan Kecamatan Plosoklaten Kabupaten Kediri adalah pembelajaran dimulai dari orang tua menerima RPPM (kegiatan yang akan anak kerjakan selama seminggu) dan RPPH serta alat dan bahan pembelajaran.

\section{Pembahasan}

Ketika anak melakukan kegiatan belajar di rumah, maka orang tua berperan sebagai pembimbing anak. Proses pembelajaran dari rumah meliputi: 1) kegiatan pendahuluan, yaitu orang tua dan anak berdo'a bersama sebelum belajar, membaca surah pendek, membaca do'a pendek. Selanjutnya, orang tua menjelaskan kegiatan hari ini yaitu tentang bebek, melihat video yang dikirim guru tentang bebek yang dipandu oleh orang tua dan melihatnya secara berulang-ulang agar anak menjadi faham tentang bebek; 2 ) kegiatan inti, yaitu anak diajak menirukan jalannya binatang bebek, kemudian membuat gambar telur bebek menggunakan krayon; 3) kegiatan penutup, yaitu orang tua membantu anak untuk mengingat kembali pengalaman kegiatan yang telah di lakukan bersamasama hari ini, orang tua memotivasi anak dengan beberapa pertanyaan, misalnya: binatang apa yang dilihat oleh anak; siapa yang menciptakan binatang bebek. Akhir kegiatan belajar dirumah maka orang tua menutup kegiatan dengan do'a sesudah belajar. Kegiatan yang telah selesai dikerjakan dilaporkan berupa foto atau video kepada guru melalui media daring whatsapp.

Adanya dukungan dari orang tua kepada anak selama aktivitas belajar dari rumah ini dapat membantu anak untuk mencapai perilaku disiplin, seperti halnya mengisi daftar hadir tepat waktu, memakai pakai rapi, berdoa dengan tertib dan berusaha mengerjakan tugas (Yasin, 2021). Senada dengan hal tersebut, Pratiwi dan Zulminiati (2021) juga mengemukakan bahwa orang tua melaksanakan perannya dengan baik ketika mengenalkan konsep bilangan pada belajar dari rumah. Keterlibatan orang tua tersebut mampu menjadikan pembelajaran di rumah menjadi lebih baik, meskipun adanya kesulitan orang tua dalam menumbuhkan minat belajar anak dalam mengenali konsep bilangan. Hasil studi literasi yang dilakukan oleh Rahmadina dkk. (2021) menjelaskan bahwa salah satu keberhasilan pembelajaran anak usia dini di rumah adalah adanya dukungan dari orang tua kepada anak berupa dukungan instrumental, penghargaan, semangat, motivasi, perhatian, dan membantu anak dalam proses pembelajaran.

Menurut Fujiawati dkk. (2020) menjelaskan bahwa pemanfaatan media yang dilakukan oleh guru PAUD dalam melaksanakan kegiatan belajar dari rumah di masa pandemi ini paling optimal 
adalah menggunakan aplikasi whatsapp. Selaras dengan hal tersebut, Widyawati (2021) mengemukakan strategi pembelajaran daring yang dilakukan oleh guru PAUD saat pandemi covid19 dilakukan melalui jaringan online seperti sosial media melalui whatsapp grup maupun pesan teks dan telepon. Strategi tersebut merupakan salah satu solusi bagi guru PAUD yang telah melaksanakan pembelajaran dari rumah, sehingga pembelajaran dari rumah dapat berjalan dengan baik sesuai dengan tujuan pendidikan. Lebih lanjut, menurut Hariyani (2020) mengemukakan pembelajaran dari rumah membantu untuk anak usia dini menunjang metode pembelajaran yang terjadi, seperti penggunaan video terbukti efektif dapat meningkatkan inovatif serta kualitas belajar dari rumah di masa pandemi covid-19.

Sisi yang lain, orang tua dapat menerapkan gaya pengasuhan otoritatif selama masa pandemic covid-19 yang memberikan dampak positif bagi orang tua dan anak ketika melaksanakan pembelajaran dari rumah. Senada dengan hal tersebut, Larzelere dkk. (2013) menyatakan bahwa orang tua dengan gaya pengasuhan otoritatif dapat memberikan bimbingan dan motivasi ketika terlibat dalam belajar anak dan sikap sabar ketika memberikan konsekuensi tindakan kepada anak. Adanya peran orang tua dalam mendampingi belajar anak di rumah adalah sebagai upaya mendukung kegiatan akademik sekolah dan memberikan implikasi positif bagi sistem Pendidikan (Đurišić \& Bunijevac, 2017), misalnya keterlibatan ayahanda dalam membentuk kemandirian dan kompetensi anak (Muna \& Sakdiyah, 2015).

\section{KESIMPULAN}

Kesimpulan penelitian ini adalah penerapan pembelajaran tatap muka new normal masa pandemi covid-19 di Taman Kanak-kanak Dharma Wanita Klanderan II Desa Klanderan Kecamatan Plosoklaten Kabupaten Kediri sesuai dengan protokol kesehatan yang telah di tetapkan oleh pemerintah, baik pemerintah pusat maupun pemerintah daerah. Sisi yang lain, untuk menunjang pembelajaran tatap muka secara langsung tersebut, lembaga Taman Kanak-kanak Dharma Wanita Klanderan II Desa Klanderan Kecamatan Plosoklaten Kabupaten Kediri juga menerapkan pembelajaran daring atau belajar dari rumah dengan pelibatan orang tua anak didik yang sangat kooperatif. Kegiatan ini dilakukan sebagai bentuk solusi agar tetap terlaksananya proses pembelajaran, baik pembelajaran luring berupa belajar tatap muka terbatas dan pembelajaran daring berupa belajar dari rumah dengan karakteristik pelaksanaan yang berbeda.

Kami menyarankan pada Lembaga Taman Kanak-kanak Dharma Wanita Klanderan II Desa Klanderan Kecamatan Plosoklaten Kabupaten Kediri untuk merencanakan beberapa hal dalam melaksanakan pembelajaran masa new normal ini, yaitu merancang kurikulum darurat selama pandemi covid-19, perubahan waktu masuk dan pulang sekolah, menerapkan protokol Kesehatan, meningkatkan perilaku hidup bersih dan sehat di lingkungan sekolah. Saran bagi orang tua dalam mendamping belajar anak di rumah adalah supaya orang tua lebih intensif dan memastikan anak tetap merasa dicintai, serta orang tua dapat memahami perubahan perilaku anak ketika aktivitas belajar secara daring di rumah. Implikasi penelitian ini adalah guru dan orang tua perlu meningkatkan adaptasi pembelajaran masa kenormalan baru ini dan menjaga hati mengelola emosi positif agar tidak mengalami konflik internal, seperti halnya mengalami stres dan kelelahan emosional.

\section{DAFTAR PUSTAKA}

Bona, M. (2021). Kemdikbudristek: $85 \%$ sekolah siap gelar pembelajaran tatap muka terbatas. https://www.beritasatu.com/nasional/829497/kemdikbudristek-85-sekolah-siap-gelarpembelajaran-tatap-muka-terbatas

Creswell, J. W. (2015). Educational research: Planning, conducting, and evaluating quantitative and qualitative research [Riset Pendidikan: Perencanaan, pelaksanaan, dan evaluasi riset kualitatif dan kuantitatif] (H. E. Soetjipto \& S. M. Soetjipto (eds.)). Yogyakarta: Pustaka Pelajar.

Đurišić, M., \& Bunijevac, M. (2017). Parental involvement as a important factor for successful education. CEPS Journal, 7(3), 137-153. 
Fahlena, H. (2021). Peran dan kendala orang tua dalam mendampingi anak belajar di rumah pada masa pandemi covid-19. Proceeding: Islamic University of Kalimantan. https://ojs.uniskabjm.ac.id/index.php/PIUOK/article/view/4738

Fujiawati, F. S., Raharja, R. M., \& Iman, A. (2020). Pemanfaatan teknologi untuk pendidikan anak usia dini di masa pandemi covid-19. Prosiding Seminar Nasional Pendidikan FKIP, 3(1), 120-125. https://jurnal.untirta.ac.id/index.php/psnp/article/view/9922

Handoyo, H. (2020). Unesco: Wabah virus corona ancam pendidikan 300 juta siswa. https://internasional.kontan.co.id/news/unesco-wabah-virus-corona-ancam-pendidikan-300juta-siswa

Hariyani, I. T. (2020). Pengembangan pembelajaran model bdr (belajar di rumah) untuk meningkatkan inovatif dan kualitas belajar anak usia dini di masa pandemi covid-19. Jurnal Lentera Anak, 1(01), 39-52.

Hijriati, H. (2017). Pengembangan model pembelajaran pendidikan anak usia dini. Bunayya : Jurnal Pendidikan Anak, 3(1), 74-92.

Kemdikbud. (2020a). Pelaksanaan kebijakan pendidikan dalam masa darurat penyebaran corona virus disease (COVID-19). https://pusdiklat.kemdikbud.go.id/surat-edaran-mendikbud-no-4tahun-2020-tentang-pelaksanaan-kebijakan-pendidikan-dalam-masa-darurat-penyebarancorona-virus-disease-covid-1-9/

Kemdikbud. (2020b). Pencegahan corona virus diseases (COVID-19) pada satuan pendidikan. https://www.kemdikbud.go.id/main/blog/2020/03/surat-edaran-pencegahan-covid19-padasatuan-pendidikan

Kompasiana, T. (2021). Pembelajaran tatap muka terbatas untuk anak usia dini. https://www.kompasiana.com/poetri75151/6180ca428777f638d757d422/pembelajaran-tatapmuka-terbatas-untuk-anak-usia-dini.

Larzelere, R., Morris, A., \& Harrist, A. (2013). Authoritative parenting: Synthesizing nurturance and discipline for optimal child development. American Psychological Association.

Lisa, R. A. (2018). Analisis pembelajaran klasikal semi kelompok terhadap perkembangan sosial emosional anak usia dini 5-6 tahun di Tk Aisyiyah 10 Surabaya. Pedagogi : Jurnal Anak Usia Dini Dan Pendidikan Anak Usia Dini, 4(1), 90-103. https://doi.org/10.30651/PEDAGOGI.V4I1.3609

Listiningrum, H., Wisetsri, W., \& Boussanlegue, T. (2020). Principal's entrepreneurship competence in improving teacher's entrepreneurial skill in high schools. Journal of Social Work and Science Education, 1(1), 87-95. https://doi.org/10.52690/JSWSE.V111.20

Menteri Pendidikan Dan Kebudayaan, Menteri Agama, Menteri Kesehatan, \& Menteri Dalam Negeri. (2021). Panduan penyelenggaraan pembelajaran di masa pandemi coronavirus disease 2019 (covid-19). https://jdih.kemdikbud.go.id/arsip/SKB 4 MENTERI PANDUAN PEMBELAJARAN TATAP MUKA.pdf

Mufaziah, E., \& Fauziah, P. (2020). Kendala orang tua dalam mendidik anak usia dini pada saat pandemi covid 19. Jurnal Obsesi : Jurnal Pendidikan Anak Usia Dini, 5(2), 1045-1051. https://doi.org/10.31004/OBSESI.V5I2.746

Mulyasa, H. E. (2012). Manajemen Paud. Bandung: PT. Remaja Rosdakarya.

Muna, L. N., \& Sakdiyah, E. H. (2015). Pengaruh peran ayah (fathering) terhadap determinasi diri (self determination) remaja [The influence of the father's role on adolescent self-determination]. Psikoislamika: Jurnal Psikologi Dan Psikologi Islam, 12(1), 45-50. https://doi.org/10.18860/psi.v12i1.6394

Pangastuti, R. (2001). Edutaiment Paud. Bandung: Penerbit Pustaka Pelajar.

Pratama, R., \& Mulyati, S. (2020). Pembelajaran daring dan luring pada masa pandemi covid-19. Gagasan Pendidikan Indonesia, 1(2), 49-59. https://doi.org/10.30870/GPI.V1I2.9405

Pratiwi, C., \& Zulminiati, Z. (2021). Peran orang tua mengenalkan konsep bilangan pada pelaksanaan belajar dari rumah (BDR). Edukids: Jurnal Pertumbuhan, Perkembangan, Dan Pendidikan Anak Usia Dini, 18(2), 124-133. https://doi.org/10.17509/EDUKIDS.V18I2.36491

Prima, E. (2020). UNESCO: 850 juta siswa di 102 negara tidak sekolah karena corona. 
https://tekno.tempo.co/read/1321347/unesco-850-juta-siswa-di-102-negara-tidak-sekolahkarena-corona

Rahmadina, F. S., Rahmadina, F. S., \& Firmiana, M. E. (2021). Bentuk dukungan orang tua pada anak usia dini (aud) selama belajar dari rumah (bdr). Jurnal Anak Usia Dini Holistik Integratif (AUDHI), 4(1), 18-25. https://doi.org/10.36722/JAUDHI.V4I1.629

Sadikin, A., \& Hamidah, A. (2020). Pembelajaran daring di tengah wabah covid-19. BIODIK, 6(2), 214224. https://doi.org/10.22437/BIO.V6I2.9759

Safitri, H. I., \& Harun, H. (2020). Membiasakan pola hidup sehat dan bersih pada anak usia dini selama pandemi covid-19. Jurnal Obsesi : Jurnal Pendidikan Anak Usia Dini, 5(1), 385-394. https://doi.org/10.31004/OBSESI.V5I1.542

Shaleh, M., \& Anhusadar, L. O. (2021). Kesiapan lembaga PAUD dalam pembelajaran tatap muka pada new normal. Jurnal Obsesi: Jurnal Pendidikan Anak Usia Dini, 5(2), 2158-2167. https://doi.org/10.31004/OBSESI.V5I2.1139

Simanihuruk, L., Simarmata, J., Sudirman, A., Hasibuan, M. S., Safitri, M., Sulaiman, O. K., Ramadhani, R., \& Sahir, S. H. (2019). E-Learning: Implementasi, strategi dan inovasinya. In Yayasan Kita Menulis. Yayasan Kita Menulis.

Sugiyono. (2017). Metode penelitian kuantitatif, kualitatif, dan R\&D. Bandung: Alfabeta.

Suhendro, E. (2020). Strategi pembelajaran pendidikan anak usia dini di masa pandemi covid-19. Golden Age: Jurnal Ilmiah Tumbuh Kembang Anak Usia Dini, 5(3), 133-140. https://doi.org/10.14421/JGA.2020.53-05

United Nations. (2020). Education during COVID-19 and beyond. https://www.un.org/development/desa/dspd/wpcontent/uploads/sites/22/2020/08/sg_policy_brief_covid-19_and_education_august_2020.pdf Utomo, H. B., Iswantiningtyas, V., Raharjo, I. B., \& Kurniawan, D. R. (2021). IbM strategi pembuatan alat permainan edukatif kearifan lokal berbasis teknologi informasi bagi pendidik anak usia dini. Abimanyu: Journal of Community Engagement, 2(2), 36-42. https://doi.org/10.26740/ABI.V212.14022

Widiastita, N., \& Anhusadar, L. (2020). Bermain playdough dalam meningkatkan kecerdasan visualspasial melalui home visit di tengah pandemi covid-19. Murhum : Jurnal Pendidikan Anak Usia Dini, 1(2), 50-63. https://doi.org/10.37985/MURHUM.V1/2.17

Widyawati, W. (2021). Strategi pembelajaran pendidikan anak usia dini di masa pandemi covid -19. YAA BUNAYYA, 2(1), 25-36. https://doi.org/10.1016/j.jack

Wulandari, H., \& Purwanta, E. (2020). Pencapaian perkembangan anak usia dini di taman kanakkanak selama pembelajaran daring di masa pandemi covid-19. Jurnal Obsesi : Jurnal Pendidikan Anak Usia Dini, 5(1), 452-462. https://doi.org/10.2/JQUERY.MIN.JS

Yasin, H. (2021). Perilaku disiplin anak pada pelaksanaan belajar dari rumah (bdr) di RA AL-AKHYAR. Tematik: Jurnal Pemikiran Dan Penelitian Pendidikan Anak Usia Dini, 7(1), 52-61. https://doi.org/10.26858/TEMATIK.V7I1.20860

Zahra, A., Dermawan, K., Anggini, C., \& Eva, N. (2021). Problematika orang tua dalam mendampingi pembelajaran daring anak selama pandemi covid-19 dan solusi pemecahannya. Prosiding Seminar Nasional Psikologi UM, 83-97. http://conference.um.ac.id/index.php/psi/article/view/1923

Zulaiha, D., Lian, B., \& Mulyadi, M. (2020). The effect of principal's competence and community participation on the quality of educational services. Journal of Social Work and Science Education, 1(1), 45-57. https://doi.org/10.52690/JSWSE.V1I1.9 